\title{
MANAGEMENT CONTROL SYSTEMS AND STAKEHOLDERS' INTERESTS IN LITHUANIAN MULTINATIONAL COMPANIES: CASES FROM THE TELECOMMUNICATIONS INDUSTRY
}

\author{
Aušra Jurkštiené ${ }^{1}$, Valdonė Darškuviené2 ${ }^{2}$ Arūnas Dūda ${ }^{3}$ \\ ${ }^{1}$ ISM University of Management and Economics, Kaunas, Lithuania \\ E-mail: ausra.jurkstiene@ism.lt \\ ${ }^{2}$ Vytautas Magnus University, Kaunas, Lithuania \\ E-mail:v.darskuviene@evf.vdu.lt \\ ${ }^{3}$ UAB "Bité Lietuva", Lithuania \\ E-mail: arunas.duda@bite.lt
}

Received 12 November 2007; accepted 28 March 2008

\begin{abstract}
The paper addresses the issue of introduction and effectiveness of modern management control systems (MCS) in Lithuanian enterprises controlled by foreign owners. Modern management control systems are supposed to provide local management with useful information, reflecting firm's performance from different stakeholders' perspectives. However, the tools of management control sometimes fail in providing with this main function. Thus, the question is raised as to the extent to which performance management systems (PMS) are effective within Lithuanian telecommunication companies, when they are implemented by foreign parent companies in the rapidly changing environment of the industry.

The paper reports the findings of a survey of 78 top and middle level managers of two telecommunication companies. Results of the research indicate that differences in the effectiveness of MCS do exist due to the specifics of governance structures within the telecommunication companies. Nevertheless, it is concluded that, when used interactively, a PMS is potentially effective even if a company operates in a rapidly changing environment.
\end{abstract}

Keywords: Management control systems, effectiveness, localisation, changes, governance, stakeholders' interests, telecommunications industry, Lithuania.

\section{Introduction: Corporate governance and the telecommunications industry in Lithuania}

In the global setting, the telecommunications industry has experienced some drastic changes during the last few years, in areas such as fixed telecommunications, GSM and interconnections. The result of these changes has led to a fall in service charges coupled with increased flexibility, functionality and the overall attractiveness of the services. Introduction of new technologies has changed the role of mobile services, leading to a significant increase in mobile penetration, which now exceed fixed line communications. As the telecommunications market has reached the point of saturation, companies have introduced differentiation strategies by services, which in turn has led to a broadening range of new products. Another key characteristic of the industry is the requirement for substantial investment in equipment (exchanges), transmission facilities (wire, optical fibre lines or wireless facilities), and terminals (subscriber equipment). The high upfront investment provides an effective barrier of entry to new players in the market. Further, the high level of required investment has led to a limited number of players within the market with sharp competition among them. Another specific characteristic of the telecommunications industry is also its perceived role within society. For many years it has been viewed as providing essential public services. The increased penetration of telecommunication lines has to benefit society as a whole. Telecommunications have changed from being a discretionary or even luxury service to an essential service that should meet the demands of the majority of consumers. Due to these factors, the telecommunications industry is characterised as a strongly regulated one by governmental authorities in order to ensure that telecommunication services are supplied to in accordance with public interest.

The Lithuanian telecommunications industry can be characterized by a group of strong players, possessing significant market power. For many years, the major state owned telecommunication company "Lietuvos Telekomas", took the leading role in providing fixed line services. This role was altered as the first two GSM operators - UAB "Omnitel" and UAB "Bite GSM", founded by foreign investors, started their activities in 
1994-1995 (Tvaronavičienė, Travkina 2005). However, only network rollout and service coverage obligations were included in license requirements. This group was joined by a new rival UAB "Tele2" in 1998, as well as several smaller players which had joined the market by the year 2003 in order to compete in the GSM market. As a result of competition for market share, as well as increasing number of users, the GSM services tariffs went down dramatically. The companies continued the processes of innovation of existing services and implementation of new products. Economy of scale as well as economy of scope was crucial for their business success. Thus, the generic strategies that were chosen by the major telecommunications market players, led by foreign strategic investors and local entrepreneurs, can be defined as differentiation strategies.

Lithuanian telecommunication companies can also be characterized by the diversity of the development of their governance systems, led by privatization driven ownership changes. The sector companies can be characterised by a number of ownership structures. First one, driven by staged privatization of the state owned telecommunications monopoly. After the stages of partial sale to foreign strategic investor, followed by open offering of state owned shares in the local stock exchange, the mixed ownership structure emerged. The company shareholder structure was formed of one major owner along with a huge number of minority shareholders. Active secondary market for company shares allowed for establishing the market control mechanisms. The introduced governance structure included groups of stakeholders, with clearly expressed diverse and conflicting economic interests (majority foreign shareholder vs minority shareholders, majority foreign shareholder vs local management, foreign parent company management vs local company management, etc.). Typically shareholders of such public companies are united by a common desire to maximize return for a given level of risk, or as currently declared more often, to maximize the shareholder value added.

The other companies from the telecommunications industry represent entrepreneurship corporations, created by entrepreneurs, governing the companies from the start, and/ or employing managers. Thus, consistent with the theory and research on corporate governance within entrepreneurial firms (Dalton et al. 2005), the contractual governance systems within these companies led to formation of stakeholder groups with economic interests differing within specific companies (i.e. foreign founders/entrepreneurs vs local managers, local founders/entrepreneurs vs local managers, local founders/entrepreneurs vs new foreign shareholders).
Governance of such firms, which receive ongoing operational resources from shareholders (founders) is much more complicated. Managers of parent companies have to reach balance between the specific interests of owners of the parent companies and the overall interests and health of the owned subsidiary.

Intensive competition within the local market (as well as globally), a diverse range of products offered, high levels of specific groups of costs, specific roles of particular groups of influential stakeholders and goals posed by them, required new types of managerial control systems to be applied within companies in order to ensure effective governance.

\section{Management control systems and their effectiveness}

Management Control Systems (MCS), as a set of formal and informal mechanisms (structure and processes), provide managers with information for decision making and evaluation of prior decisions. The role of MCS increases with the growing structural complexity of the modern multinational corporation. According to some researchers (Porporato 2004), “...55 \% of strategic alliances fall apart within three years and only $23 \%$ recover the costs ... Among the causes of these failures the press points at the lack of a common culture, open communication and individual personalities... the bottleneck is an incompatibility of cultures in the $42 \%$ of the cases, followed by a $22 \%$ of cases where the problem was rooted in the management accounting information systems".

MCS have evolved in organisations for two main purposes: first, they serve as a tool ensuring goal coordination among managers representing different entities of corporation and different hierarchical levels; and on the other hand, MCS should facilitate the monitoring of performance results. Both purposes should motivate manager's behaviour towards organisational goals. The balance between those two main roles differs in each organisation, reflecting an individual governance style of an organisation and the environmental complexity and uncertainty, which an organisation tempts to deal with. The useful MCS, therefore, must help owners to coordinate and monitor the agents' behaviour.

Therefore, the more complex the organisation, the more complex MCS it requires. On the other hand, it is obvious that establishing and developing useful and complex MCS means the creation of additional formal structures and processes, which demands managerial effort, time and costs. Are those attempts adequate to 
an organisation and its purposes, which develop and change over time? Aren't the informational and reporting structures of MCS insufficient or conversely overcrowded with the measures which managers never use in decision making? These questions arise with the new business issues, as the speed of contextual changes increases, especially in telecommunications, and the periods of emerging strategies become shorter.

In the broad sense, we propose to define the effectiveness of a particular Management Control System as its ability to fulfil the roles of coordinating and monitoring using the most unformal structures.

According to Agency Theory (Jensen and Meckling 1976), an organisation is treated as a set of contracts between individual principals and agents, resolving the potential conflicts of their interests. The classical interpretation and further development of the theory lead to shareholder primacy model. According to it those formal and informal contracts keep the organization oriented towards the owners' interests, namely - the growth of shareholder value. Alternative stakeholder models stem from characteristics of incomplete contracts (e.g. Hart 1995), arguing that discretionary actions of managers are executed consistently with interests of other stakeholders. Shareholders are just one group of stakeholders, having possibility to execute claims against residual assets. Therefore, their interests should not enjoy priority over the interests of other stakeholders. Another group of researchers concentrate on corporate governance within entrepreneurship firms (Dalton et al. 2005), drawing attention to strategic leaders within entrepreneurship firms, and arguing that the choice of various governance structure options could be associated with firm performance. Thus areas of efficient governance, possibilities to implement strategic changes in order to enhance strategic performance are being analysed, and roles of specific stakeholders (entrepreneurs/ founders) as key determinants of performance are discussed. In spite of the diversity of approaches and models, financial performance indicators are used most often. The role of managers is seen as specific one, aligning goals of different groups of stakeholders, in the best case towards common direction.

This rational view laid the basis to traditional planning, performance measuring and reporting systems, where the dominant valuation perspective reflects the financial success of the business entity. From this point of view, the MCS is treated as more effective, if it enables managers to measure the goals and outcomes more objectively in financial terms. The later theoretical assumption explains why the financial accounting and reporting systems have been developed into the most popular and complex business information systems today, and why the financial indicators are so widely used to monitor business performance. Financial indicators as Sales, Operational and Net Profit as well as the Free Cash Flows provide gross financial figures, while Return On Equity (ROE), Return On Assets (ROA) ratios indicate how effectively an organisation raises financial funds and manages its assets. On one hand, information about financial indicators enables existing and potential owners to measure financial success of business by one-year period outcomes, but on the other hand, those indicators boost the one-year period planning and control procedures in overall management practice. Performance measurement problems consequently may arise, if MCS is based exceptionally on financial outcomes and if managers' compensation and reward systems are related solely to current financial performance measures. While short-termism and risk-awareness prevail against the strategic thinking, such practices may boost the negative managers' behaviour: they could seek short-term goals, scarifying the long-term organisational strategy. This may induce managers to avoid innovative investment decisions. In the worst case manipulation with accounting numbers may occur.

Traditionally, financial measures have dominated performance reports for monitoring purpose, even if they have very limited ability to fulfil the coordination task of control - to motivate managers, to seek goal congruence between different groups of stakeholders, to ensure learning. Formal financial reporting systems cannot provide sufficient informational structure per se, not to mention the problem of their effectiveness. The latter problems of traditional PMS have inspired the growing interest of managers for non-financial performance measures, which have led to the worldwide "revolution" in performance measurement. New management tools have become popular ("The Balanced Scorecard", "The Performance Prism", "The Performance Measurement Matrix", "The SMART pyramid") which propose an extended framework of performance indicators, introducing some additional performance measurement perspectives to the financial set of measures. Those additional perspectives reflect the broader scope of strategic organisation goals, rising from different stakeholder's interests (shareholders, customers, employers, society), e.g. the "Balanced Scorecard" involves "shareholders", "customers", "business process" and "learning and growth" measurement perspectives. The modern PMS promises a way to cascade the organisational strategy into the system of measurable and congruent goals and individual tasks. Those meas- 
ures provide information that stimulates more effective decision making and long-term strategic thinking by managers across different levels and functional departments. Therefore the balance shifts from a monitoring to a coordinating role of MCS. The above mentioned systems (e.g., "Balanced Scorecard") have become popular in Lithuanian subsidiaries of multinational companies, as they are expected to help parent-companies to adapt their management practices locally.

However, new threats arise while constructing new PMS: "Organisations are implementing new measures to react to new priorities, but failing to discard measures reflecting old priorities" (Meyer and Gupta 1994). The growing complexity of the formal system causes the decrease of its ability to reflect the changes in goals and priorities in changing business environment. The PMS information scope becomes too large to use it effectively. Having in mind increasingly changing environment, can any PMS still operate effectively? The contingency theory (Emmanuel et al. 1995) suggests a positive answer, however it shifts attention from the complexity problem to the way of implementing PMS and its adaptation to the contingent organizational factors (size, interdependence, decentralization and resource availability) as well as environmental factors (predictability, the degree of competition faced in the market place, the number of different products/markets encountered, and the degree of hostility exhibited). The effectiveness of MCS could be described also through its ability to ensure organizational learning, focus, commitment and capability, balancing the degree of adaptive versus generative characteristics of MCS (Herremans and Isaac 2005).

Following theory, the way of PMS usage becomes a differential factor of the same importance as the complexity of the PMS, both defining the effectiveness of the MCS. According to our view, modern effective PMS are supposed not only to provide local management with useful information, but should have a wider content, i.e. should be intended to reflect and monitor a firm's performance from different stakeholders' perspectives, including company shareholders, managers, employees, customers.

We argue that international companies, operating in the stable environment, face the problems of the effectiveness of MCS, which arise in the process of their localization to the changing environment of growing economies. Performance indicators which are introduced in these Lithuanian companies, are usually a long-term result of development of MCS within foreign companies, reflect their approaches towards company goals, and their congruence from different stakeholders' per- spectives. However, the observations in Lithuanian telecommunication companies indicate some factors of their ineffectiveness.

We believe that within the local companies balance between long-term and short-term performance indicators does not reflect properly specific interests of different stakeholders. Different types of conflicts may arise, including the ones between management of parent and local companies concerning their attitudes towards which groups of performance indicators reflect better the performance results within local companies. Local management of Lithuanian telecommunication companies argue that tools of management control may fail in the main function, i.e. in reflecting a firm's performance from different stakeholders' perspectives, which could indicate the problem of their effectiveness.

In summary, the paper provides insight into problem of the scale of the ineffectiveness of MCS within Lithuanian companies based on survey of management of two companies from the telecommunications industry. The main aim of the paper is to assess the effectiveness of formal PMS that are implemented within companies with two different governance structures (with market based control and with prevailing internal control mechanism) by foreign parent companies into the rapidly changing environment of the Lithuanian telecommunications industry.

\section{Research method}

For research purposes, we have narrowed the definition of PMS' effectiveness and assume that the following characteristics represent effective monitoring and coordinating functions of PMS:

1. It helps managers of different levels of authority and different functional responsibilities to identify common priorities among organisational success factors.

2. It has sufficient complexity - number of performance indicators to identify the goals of organisation from the main performance measurement perspectives: financial, customer, business process, learning and growth.

3. The majority of performance measures reflecting primary goals of different groups of stakeholders of the companies are used interactively (ensure support for decision making) rather than diagnostically (reporting) by the managers.

The support of existing formal systems to the local managers in decision making, ensuring goal congruence between groups of stakeholders, is the main criterion to distinguish between effective and ineffective PMS. 
The survey of the 78 top and middle level managers of two telecommunication companies was carried out in 2006 in order to explore the above mentioned characteristics of PMS effectiveness, and detect the main problems of adopting formal PMS to the local companies with foreign ownership, operating in the rapidly changing environment.

The survey included two companies with foreign ownership. One of them is a public company, with one major shareholder and large group of minority shareholders. Another one is a privately held firm with concentrated ownership, founded as an entrepreneurship company with several subsequent changes in ownership structure. Having in mind the diversity of governance structures, stakeholders' interests and operating history of two companies, we assume, that effectiveness of MCS within these companies should differ in their ability to fulfil the monitoring and coordinating roles.

The first part of the questionnaire contained a list of key success factors describing the specifics of the telecommunication market. They were asked to evaluate the importance of each factor on a ten-point scale. The second part contained a list of performance indicators, representing four perspectives of performance measurement, as proposed by Balanced Scorecard: financial, customer, internal process, organisational development and growth. The respondents were asked to identify the way of usage of each particular indicator by the following scale:

"1" - indicator is unknown, or it is not used in PMS system of organisation,

"2" - indicator is implemented somewhere in the company, but it is not relevant for the respondent,

" 3 " - indicator is used for the reporting purposes of the respondents' department,

"4" - indicator is useful for the performance measurement and reward system of respondents' department,

"5" - indicator is useful for the decision making by the respondent.

Therefore, the range from 4 to 5 points represents the interactive usage of PMS, the range from 3 to 4 points means diagnostic (formal reporting) character of PMS usage and represents the monitoring role of PMS, while the answers from 1 to 2 points show, that PM indicator is not present in the management control system.

\section{Results and findings}

Comparing answers of different management level, it is evident that all Performance Indicators (PI) were used more actively by top-level managers in both companies than by the managers of the middle level (the means of evaluations were 4.4 versus 2.8 points respectively). The fact illustrates the situation that the performance measurement system is more used for monitoring outcomes of agents' performance, rather than coordinating their behaviour or ensuring the organisational learning. The evidence was common for all the sample, therefore the attribute of management level will not be used in further analysis, seeking to explain the differences in PMS effectiveness by other sample characteristics, namely - organisation and functional department.

1. Does PMS help the managers with different functional responsibilities to identify the common priorities among organisational success factors?

The results, presented in Table 1 show, that none of the success factors in both companies was treated uniformly as a leading one. All the factors were ranked by respondents as "important" (8 points), "very important" (9 points) or "of critical importance" (10 points). However, from the first high-ranked factor we can identify the competitive strategies of the companies: Company A is oriented to service quality by new technology, while Company B emphasises the importance of customer service. It corresponds to the fact that competing Lithuanian telecommunication companies choose differentiation strategies. Generally, local managers execute well the main strategic trend of the

Table 1. Key success factors of two companies (mean)

\begin{tabular}{lclc}
\hline \multicolumn{1}{c}{$\begin{array}{c}\text { Key success factors } \\
\text { of Company A }\end{array}$} & \multicolumn{2}{c}{$\begin{array}{c}\text { Key success factors } \\
\text { of Company B }\end{array}$} \\
\hline New technology & 9.0 & Customer service & 9.1 \\
\hline Service Quality & 8.8 & Service Quality & 8.9 \\
\hline $\begin{array}{l}\text { Organisational } \\
\text { culture }\end{array}$ & 8.7 & Company's prestige & 8.8 \\
\hline $\begin{array}{l}\text { Employee } \\
\text { motivation }\end{array}$ & 8.7 & New technology & 8.8 \\
\hline Cost and efficiency & 8.7 & Employee motivation & 8.6 \\
\hline Customer service & 8.6 & Cost and efficiency & 8.4 \\
\hline $\begin{array}{l}\text { Return On } \\
\text { Investment }\end{array}$ & 8.5 & Organisational culture & 8.4 \\
\hline Company's prestige & 8.4 & Return On Investment & 8.2 \\
\hline Service price & 8.0 & Service price & 8.0 \\
\hline
\end{tabular}


company, but the question of coordination remains: how do managers of different levels and functional departments in the same company treat the same priorities? Further analysis shows that the main priority of company B, i.e. customer service, was ranked in the first place by managers of all functional departments, while in the Company A the top-factors were ranked differently in each functional department. It could mean lack of strategy communication and goal coordination between managers of Company A. Managers of the technology departments of both companies were not able to distinguish between the relevant importance of the factors, as they evaluated all of them as critically important.

2. Does PMS have sufficient complexity (list of performance indicators) to identify the goals of organisation from the main performance measurement perspectives: financial, customer, business process, learning and growth?

This question leads to the analysis of the monitoring role of PMS. The analysis of PMS financial and customer perspectives of both companies was made by functional departments (Marketing, Technology and Finance) represented by managers, as this attribute could explain the differences in effectiveness of the MCS between two companies.

Comparing the lists of gross financial PM indicators between the two local companies (see Table 2), it could be seen that managers of company A use a set of financial performance indicators for decision making and performance evaluation while the managers of Company B only report on some financial indicators. The complexity of financial PMS is low in this company, and its usage is formal.
Managers of both companies use a narrow set of financial indicators (such as Sales, Net profit and Cash flows) for decision making and reporting, however they do not use financial ratios - efficiency indicators (Sales to Assets, Return on Equity, EVA) for those purposes (exception- the measure of Return On Investment). The situation indicates that local managers are oriented towards short-term financial goals. Such measuring practice, especially if it is correlated with the reward system, as in Company A (see Table 2), orients managers towards extensive growth rather than effectiveness in fund using, asset allocation, and subsequently the goals of substantial growth of organisation and value creation are not obvious.

Those results could also indicate that the local managers do not report on financial ratios, because they probably do not have sufficient independency to make decisions concerning financing and asset utilisation, or strategies of the companies are not primarily oriented towards financial effectiveness. Here, the financial perspective reflects non-financial priorities of the key success factors, identified in both companies (see Table 1). The coordination role of MCS in this case must be realised by the non-financial perspectives of PMS.

The survey showed, that managers of all functional departments use performance indicators, representing the Customer Perspective (see Table 3). However, differences between two companies are quite obvious. While managers of Company A use from 4 to 7 indicators for decision making and reporting purposes in all departments, only technology managers report on 7 performance indicators in Company B (evaluations vary from 3.0 to 3.6 points). The managers of marketing and finance departments of Company B do not

Table 2. Financial PI usage by managers of companies A and B (mean)

\begin{tabular}{lcccccc}
\hline \multirow{2}{*}{ Financial perspective PI } & \multicolumn{2}{c}{ Marketing managers } & \multicolumn{2}{c}{ Technology managers } & \multicolumn{2}{c}{ Financial managers } \\
\cline { 2 - 7 } & A & B & A & B & A & B \\
\hline Sales Revenues & 4.5 & 2.4 & 3.5 & 3.6 & 4.8 & 3.0 \\
\hline Operational Profit (EBITDA) & 4.5 & 2.6 & 3.5 & 4.1 & 5.0 & 3.0 \\
\hline Return On Investment (ROI) & 4.3 & 1.9 & 3.5 & 3.8 & 4.3 & 2.0 \\
\hline Net Profit & 4.0 & 2.1 & 3.5 & 3.5 & 4.8 & 2.6 \\
\hline Cash flow & 4.0 & 2.1 & 3.5 & 3.6 & 3.5 & 2.2 \\
\hline Return On Equity (ROE) & 2.3 & 1.6 & 2.0 & 1.2 & 2.8 & 1.8 \\
\hline Return On Assets (ROA) & 2.3 & 1.6 & 2.0 & 1.1 & 3.5 & 1.9 \\
\hline EVA & 2.2 & 1.6 & 1.5 & 1.3 & 2.3 & 1.6 \\
\hline Sales to Assets & 1.5 & 1.6 & 2.0 & 1.2 & 2.0 & 1.8 \\
\hline
\end{tabular}


Table 3. Customer perspective PI usage by managers of companies A and B (mean)

\begin{tabular}{|c|c|c|c|c|c|c|}
\hline \multirow{2}{*}{ Customer perspective PI } & \multicolumn{2}{|c|}{ Marketing managers } & \multicolumn{2}{|c|}{ Technology managers } & \multicolumn{2}{|c|}{ Financial manager } \\
\hline & $\mathbf{A}$ & B & $\mathbf{A}$ & B & $\mathbf{A}$ & B \\
\hline Market share on target segments & 4.5 & 2.9 & 3.5 & 3.6 & 5.0 & 2.8 \\
\hline Growth of No. of Customers & 4.5 & 2.7 & 3.5 & 3.5 & 5.0 & 2.5 \\
\hline ARPU & 4.5 & 2.8 & 3.5 & 3.5 & 4.3 & 2.5 \\
\hline Market growth & 3.5 & 2.8 & 2.0 & 3.1 & 4.3 & 2.4 \\
\hline Price indices & 3.5 & 2.8 & 2.0 & 2.7 & 4.3 & 2.1 \\
\hline Customer satisfaction index & 3.5 & 2.5 & 2.0 & 3.0 & 2.8 & 2.6 \\
\hline Brand awareness & 3.3 & 2.8 & 2.0 & 2.1 & 3.5 & 2.7 \\
\hline Customer profitability & 3.0 & 2.4 & 2.0 & 3.3 & 3.5 & 2.5 \\
\hline Cost of customer attraction & 2.7 & 2.8 & 2.0 & 3.0 & 2.5 & 2.8 \\
\hline Period of Customer & 2.2 & 2.5 & 2.0 & 2.6 & 2.5 & 2.2 \\
\hline
\end{tabular}

report on the Customer perspective basis, however they are familiar with those performance indicators (evaluations vary from 2.1 to 2.9 points).

Factors of competition in the changing telecommunications market, technological advantages and innovations are substantial for both companies. Therefore effective performance measurement on the business process perspective is very important. Companies use from 5 to 7 performance indicators in their PMS to monitor the main aspects of the business process and its quality (see Table 4). However, only managers of Company A use the most important measures interactively. Managers of all functional departments agree, that new technology and service quality factors are the most important for Company A (see Table 1). The per- formance indicators of the Company A business process perspective (see Table 4) are aligned well towards these priorities, as the managers use such indicators as investments to the network, investments to the new technology, costs and profits of activities, service profitability while considering the managerial decisions. Again, managers of different functional departments agree on the two main performance indicators: investments to the network, investments to the new technology. This situation illustrates good coordination and goal congruence in Company A.

The situation differs with the PMS of Company B (see Table 4), where none of the indicators are used for decision making by managers, but for reporting purposes only (evaluations are below 4 points). Only the

Table 4. Business Process perspective PI usage by managers of companies A and B (mean)

\begin{tabular}{lllllll}
\hline \multirow{2}{*}{ Business process perspective PI } & \multicolumn{2}{c}{ Marketing managers } & \multicolumn{2}{c}{ Technology managers } & \multicolumn{2}{c}{ Financial managers } \\
\cline { 2 - 7 } & $\mathbf{A}$ & $\mathbf{B}$ & $\mathbf{A}$ & $\mathbf{B}$ & $\mathbf{A}$ & $\mathbf{B}$ \\
\hline Investments to the Network & 4.0 & 2.8 & 3.5 & 3.7 & 4.3 & 2.0 \\
\hline Investments to the new technology & 4.0 & 2.4 & 3.5 & 2.9 & 4.3 & 2.5 \\
\hline Costs and profits of activities & 3.5 & 2.5 & 2.0 & 2.4 & 4.3 & 2.2 \\
\hline Service profitability & 3.5 & 2.5 & 2.0 & 3.1 & 4.3 & 2.2 \\
\hline Exploitation of Network Capacity & 2.8 & 2.9 & 3.5 & 3.5 & 2.8 & 2.6 \\
\hline $\begin{array}{l}\text { Geographical coverage by the } \\
\text { network }\end{array}$ & 2.3 & 2.6 & 3.5 & 3.7 & 2.8 & 2.4 \\
\hline Inventory turnover & 2.3 & & 2.0 & 3.2 & 3.5 & 2.3 \\
\hline Network congestion & 1.3 & 3.3 & 2.0 & 3.5 & 2.8 & 2.0 \\
\hline
\end{tabular}


managers of technology department report on business process indicators, while theirs relevance for marketing and finance managers is not obvious. The presence of such indicators in PMS illustrates ineffectiveness of formal PMS.

Analysis on the last performance measurement perspective: learning and growth has suggested, that it has the weakest monitoring, as the complexity and activeness of usage of these indicators is relatively low in both companies. However it corresponds to the general trend of performance measurement practice, as the measurement of the outcomes of this perspective is the most problematic and companies probably prefer to outsource the monitoring function of this perspective, rather than periodically analyse employee satisfaction and loyalty issues by themselves. The main differences in priorities and usage of learning and growth perspective indicators were determined by the management level, rather than as a functional department attribute (see Table 5).

Generally speaking, PMS have sufficient complexity for monitoring non-financial outcomes of the performance in both companies. On the other hand, the large number of indicators, never used interactively or diagnostically by managers (as in case of Company B), could illustrate the problem of over-formalisation and bureaucratic character of PMS and subsequent ineffectiveness of MCS. So, the main focus of further analysis will be put on the third characteristics of PMS effectiveness, shifting the attention from monitoring to $\mathrm{co}$ ordination role of PMS.
3. Are most of performance measures, reflecting the primary goals, related to groups of stakeholders, used interactively (supporting the decision making) rather than diagnostically (reporting) by the managers?

The survey of top-level managers of both companies showed that they use all presented list of non-financial performance measures for monitoring, reporting and decision making purposes, so the PMS of both companies supports the top-level decision making. However, the average number of PMS indicators used varies significantly between top and middle level managers (see Table 6). Differences between two companies have been identified by eliminating answers of toplevel managers from further analysis, as the problem of goal coordination is more relevant for the middle level managers.

Analysis of responses of the middle level managers of two companies shows the differences of the coordination role of PMS. Managers of different departments of Company A use common indicators to monitor the different perspectives of performance, while the managers of Company B use such indicators for decision making purposes very rarely and often have personal view on which of performance indicators have been used more actively. Managers of Company A are oriented towards main performance indicators more often, while considering business decisions.

The survey in Company A demonstrated a vivid coordination among the managers, representing different functional departments, as they ranked top the same

Table 5. Learning and growth perspective PI usage by managers of companies A and B (mean)

\begin{tabular}{lcccccc}
\hline \multirow{2}{*}{$\begin{array}{c}\text { Learning and growth } \\
\text { perspective PI }\end{array}$} & \multicolumn{2}{c}{ Marketing managers } & \multicolumn{2}{c}{ Technology managers } & \multicolumn{2}{c}{ Financial managers } \\
\cline { 2 - 7 } & $\mathbf{A}$ & $\mathbf{B}$ & $\mathbf{A}$ & $\mathbf{B}$ & $\mathbf{A}$ & $\mathbf{B}$ \\
\hline Employee loyalty & 3.2 & 1.7 & 3.5 & 3.5 & 2.8 & 2.5 \\
\hline Investments to employee training & 3.2 & 1.5 & 3.5 & 3.5 & 2.3 & 2.4 \\
\hline Employee satisfaction & 2.7 & 2.1 & 3.5 & 3.5 & 3.5 & 2.5 \\
\hline
\end{tabular}

Table 6. Usage of financial vs non-financial PI by top and middle level managers

\begin{tabular}{lcccc}
\hline \multirow{2}{*}{$\begin{array}{c}\text { Management } \\
\text { level }\end{array}$} & \multicolumn{2}{c}{ Company A } & \multicolumn{2}{c}{ Company B } \\
\cline { 2 - 5 } & $\begin{array}{c}\text { Average number of } \\
\text { financial indicators } \\
\text { used }\end{array}$ & $\begin{array}{c}\text { Average number } \\
\text { of non-financial } \\
\text { indicators used }\end{array}$ & $\begin{array}{c}\text { Average number of } \\
\text { financial indicators } \\
\text { used }\end{array}$ & $\begin{array}{c}\text { Average number } \\
\text { of non-financial } \\
\text { indicators used }\end{array}$ \\
\hline Top & 4.7 & 5.0 & 2.9 & 4.4 \\
\hline Middle & 3.0 & 3.0 & 2.1 & 2.5 \\
\hline
\end{tabular}


Table 7. Usage of PI by different performance perspectives

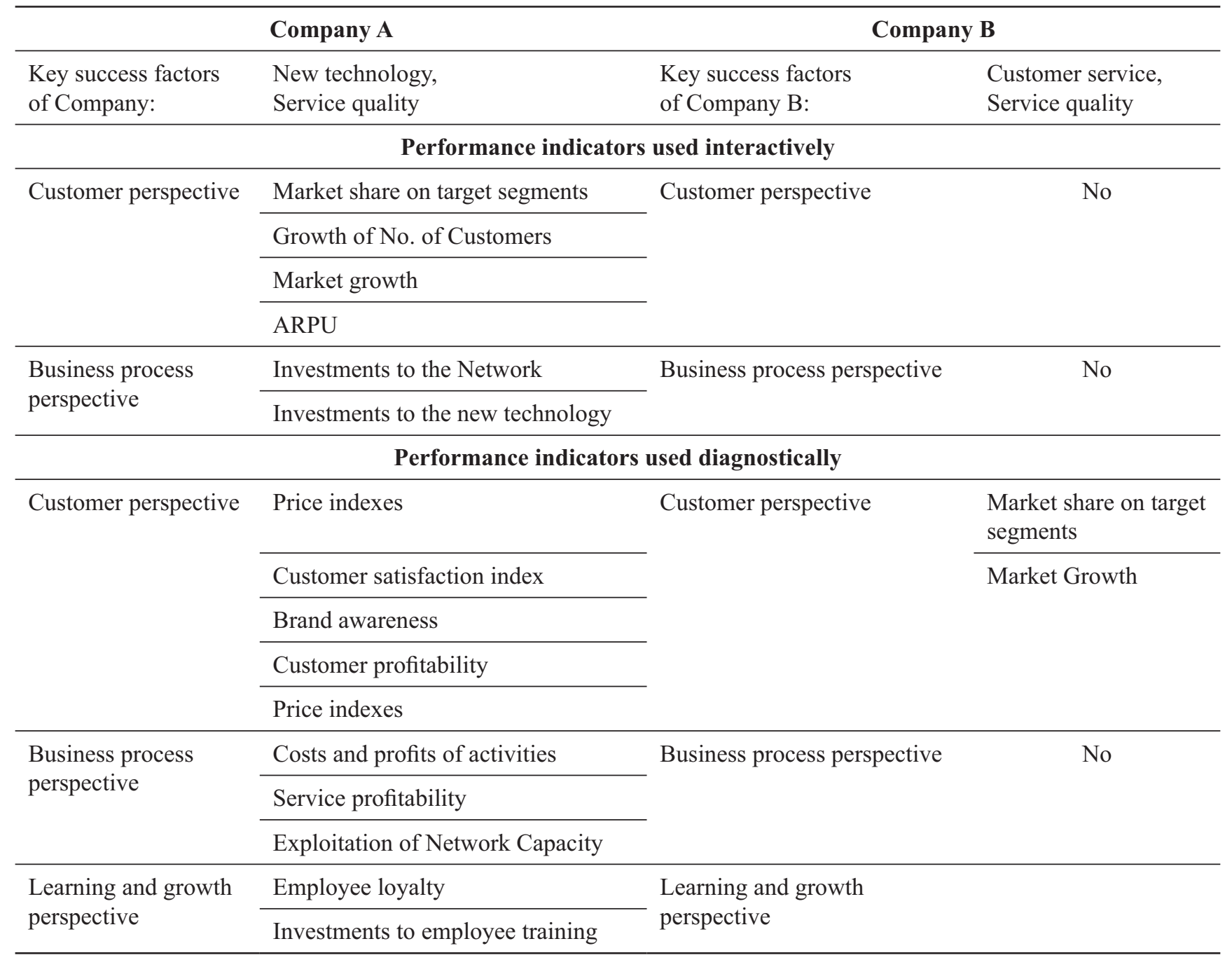

indicators in all perspectives. Such indicators as market share on target segments, number of customers, market growth, ARPU (see Table 2), investments to the network, investments to the new technology (see Table 4) have attracted the attention of many of them. It corresponds well with the non-financial strategic priorities that were uniformly ranked top within the Key Success Factors list of Company A, namely: new technology and service quality (see Table 7). Managers of marketing and finance departments use these main strategic indicators for decision making, performance measurement and reporting, while the technology managers report on their basis.

Despite the fact, that managers of Company B ranked the customer service and service quality in the top of success factors (see Table 7), the PMS system, surprisingly seems not to be able to reflect this priority, as none of the customer perspective indicators serve for decision makers. However, all of these indicators are included in PMS, which indicates ineffectiveness of the formal system.

\section{Conclusions}

The survey of managers of two Lithuanian telecommunication companies, owned by foreign investors, and differing in corporate governance structures and by major stakeholder goals, has indicated differences in efficiencies of MCS employed.

PMS of both companies contain a sufficient set of indicators, representing main perspectives: financial, customer, business process, learning and growth, however the effectiveness of those PMS differs between the companies and the management level. Top-level managers have found the PMS system to be effective supporter for decision making, whereas middle level managers rarely use PMS for decision making. The usage of non-financial performance indicators for toplevel management decision making has been prevalent in both companies, against the usage of financial indicators. The monitoring role of PMS still dominates over the coordination role among the middle level 
managers, however the balance between two differs substantially across the companies.

The analysis showed that too many success factors are mentioned as equally important by the managers of both companies. This suggests a lack of focus towards the priorities, however managers know the main strategic differentiator of their company.

Analysing the answers of the middle level managers of two companies, the differences in the coordination role of PMS could be seen. Company A demonstrate a distinguishing coordination among the managers, representing different functional departments, while the managers of Company B very rarely use common indicators for decision making purposes. In addition, the most actively used PI corresponds well with the non-financial strategic priorities that were uniformly ranked in the top of the Key Success Factors list of Company A, which indicates higher effectiveness of MCS. The PMS system of Company B does not seem able to reflect the priorities of the organisation. However, Company A still has a complex set of PI formally introduced to the accounting system, which indicates the lower effectiveness of the PMS.

Further role of PMS in cascading the strategic goals and coordinating them across the different functional departments is shown to be important, as the comparative analysis of two companies highlights that active usage of PMS helps managers to align their goals and decision making towards the main strategic priorities.

We conclude that differences in effectiveness of MCS do exist due to the specifics of governance structures within telecommunication companies that are operating in the rapidly changing market environment in Lithuania. The differences appear when considering the MCS role of coordination. While used interactively, the PMS could be effective even if company operates in this rapidly changing environment.

\section{References}

Emmanuel, C.; Otley, D.; Merchant, K. 1995. Accounting for management control. London: Chapman \& Hall.

Dalton, C. M.; McDougall, P. P.; Covin, J. G.; Dalton, D. R. 2005. Governance and strategic leadership in entrepreneurial firms, in K. Keasey, S. Thompson and M. Wright (eds.). Corporate governance. London: John Wiley \&Sons.

Hart, O. 1995. Corporate governance: some theory and implications, The Economic Journal 105: 687-689.

Herremans, I. M. and Isaac, R. G. 2005. Management planning and control supporting knowledge - intensive organizations, The Learning Organization 12(4): 313-329.

Jensen, M. and Meckling, W. 1976. Theory of the firm: managerial behaviour, agency costs, and ownership structure, Journal of Financial Economics 3(4): 305-360.

Meyer, M. W. and Gupta, A. 1994. The performance paradox, in B. M. Straw and L. L. Cummings (eds.). Research in Organizational Behaviour 16. Greenwitch, CT: JAI Press, 309-369.

Porporato, M. 2004. Configuration, design and uses of management control systems in international equity joint ventures: a theoretical and empirical study: doctoral dissertation. University of Navarra.

Tvaronavičienè, M.; Travkina, I. 2005. Telecoms' globalization and liberalization process in European Countries, Business: Theory and Practice 6(4): 60-72. 